\title{
4-Alkyl-1-(2-fluorobenzoyl)thiosemicarbazides and products of their dehydrocyclization as compounds with potential anticonvulsant activity
}

\author{
I. Czyżewska, E. Kuśmierz, M. Wujec \\ Medical University \\ 4a, Chodźki Str., Lublin, Poland, 20-093 \\ monika.wujec@umlub.pl (MonikaWujec)
}

\begin{abstract}
Aim. To accomplish the synthesis of new thiosemicarbazides and their cyclic analogues derived from 2-fluorobenzoic acid hydrazide and to evaluate further their anticonvulsant activity. Methods. Organic synthesis, NMR spectroscopy, molecular docking. Results. A number of thiosemicarbazide derivatives have been synthesized by the reaction of 2-fluorobenzoic acid hydrazide with the corresponding isothiocyanates in the ethanol medium. The subsequent alkaline dehydrocyclization of thiosemicarbazides led to some new 1,2,4-triazole derivatives. Docking studies were performed to predict the anticonvulsant activity for the synthesized compounds on GABA-A receptors and pentameric ion channels of Erwinia chrysanthemi (ELIC). Conclusions. The synthesized thiosemicarbazides and their cyclic analogues are characterized as a prospective molecular platform for the creation of new highly active compounds as potential anticonvulsant drugs.
\end{abstract}

Ke y w or d s: thiosemicarbazides, 1,2,4-triazoles, anticonvulsant activity.

\section{Introduction}

Epilepsy is one of the most common chronic neurological diseases with the prevalence of $1 \%$ in the general population affecting about 50 million people worldwide [1]. The direct causes of seizure disorders, characteristic of epilepsy, are the abnormalities of the brain's bioelectrical activities, i.e. excessive discharges. The indirect causes of epilepsy are the disrupted balances between the activity of GABA-ergic and excitatory glutamatergic sys- tems [2]. Anti-epileptic medications decrease membrane excitability by interacting with neurotransmitter receptors or by inhibiting voltage-dependent ion channels involved in the electrical propagation of the seizure [3-6].

One of the known antiepileptic drugs is Loreclezole, composed of 1,2,4-triazole. The mechanism of its action is based on the interaction between 1,2,4-triazole and amide group of aspargate (Asn-289) occurring on the $\beta 2$

(C) 2020 I. Czyżewska et al.; Published by the Institute of Molecular Biology and Genetics, NAS of Ukraine on behalf of Biopolymers and Cell. This is an Open Access article distributed under the terms of the Creative Commons Attribution License (http://creativecommons.org/licenses/by/4.0/), which permits unrestricted reuse, distribution, and reproduction in any medium, provided the original work is properly cited 
subunit of the $\mathrm{GABA}_{\mathrm{A}}$ receptor. The result of the action of Loreclezole is allosteric modulation [7].

Based on this knowledge, scientists studied the substances containing 1,2,4-triazole ring [8-11]. The chemical compounds containing 1,2,4-triazole with substituent of chlorine were analyzed and described previously $[12,13]$.

One of the methods to improve the biological activity of compounds is by using fluorine to replace chlorine in a molecule. The fluorine substitution can have a profound impact on the chemical and physical properties, drug distribution, clearance, and metabolism, and thus can affect the biological activity of drugs. It was discovered that introduction of fluorine, which has a smaller size than chloride, into the molecule caused increased lipophilicity, therefore improving the penetration through the blood-brain barrier. The fluorine atoms also contribute to a less toxicity of antiepileptic substances. This feature is associated with high electronegativity of fluorine, which causes the repulsion of electrons in the peroxisome, improving its function in the cytochrome P450 catalytic cycle responsible for drug detoxification [14].

In the presented work we described the synthesis of new thiosemicarbazide and 1,2,4-triazole derivatives with potential anticonvulsant activity.

\section{Materials and Methods}

The chemical reagents were purchased from Sigma-Aldrich (Munich, Germany). Melting points were determined on Fisher-Johns blocks melting point apparatus (Fisher Scientific, Germany) and are uncorrected. The purity of compounds and progress of the reaction were monitored by TLC (aluminum sheet 60 F254 plates (Merck Co., USA). Elemental analyses were determined by a Perkin Elmer 2400 series II CHNS/O elemental analyzer (Waltham, US) and the results were within $\pm 0.4 \%$ of the theoretical value. The ${ }^{1} \mathrm{H}$ and ${ }^{13} \mathrm{C}$ spectra were conducted using Bruker Avance 600 (Bruker BioSpin GmbH, Germany) in (D6) DMSO with TMS as the internal standard. IR were determined by Nicolet 6700 spectrometer (Thermo Scientific, US) and UV-Vis spectra were obtained in the range of 190-700 nm using UV-vis detector L2455, VWR Hitachi (Merck, Darmstadt, Germany).

\section{The procedure of synthesis of the} 1-(2-fluorobenzoyl)-4-substituted-thiosemicarbazide (1-3)

0.01 mole of 2-fluorobenzoic acid hydrazide was dissolved in ethanol. If it did not dissolve, it was softly warmed. Next 0.01 mole of suitable isothiocyanate was added by pipette. The whole mixture was heated under reflux for half an hour. The progress of the reaction was checked by thin layer chromatography. After cooling crude solid was washed with warm water, diethyl ether, dried and crystallized from $96 \%$ ethanol.

1-(2-Fluorobenzoyl)-4-(pentyl)thiosemicarbazide $1(81 \%) \mathrm{mp} 120-123^{\circ} \mathrm{C}$

${ }^{1} \mathrm{H}$ NMR $(\delta, \mathrm{ppm}): 0.92 ; 0.93 ; 0.94(\mathrm{t}, 3 \mathrm{H}$, $\left.\mathrm{CH}_{3} J=6.9 \mathrm{~Hz}\right), 1.30-1.35\left(\mathrm{~m}, 4 \mathrm{H}, 2 \mathrm{CH}_{2}\right)$, 1.54-1.59 (m, $\left.2 \mathrm{H}, \mathrm{CH}_{2}\right), 3.49-3.50(\mathrm{~m}, 2 \mathrm{H}$, $\left.\mathrm{CH}_{2}\right), 7.36-7.39$ (m, 2H, CH arom), 7.62-7.67 (m, $1 \mathrm{H}, \mathrm{CH}$ arom), 7.83; 7.86; $7.87(\mathrm{dt}, 1 \mathrm{H}$, $\mathrm{CH}$ arom, $\left.J_{1}=1.8 \mathrm{~Hz}, J_{2}=6.0 \mathrm{~Hz}\right), 7.97 ; 9.41$; $10.17(3 \mathrm{~s}, 3 \mathrm{H}, 3 \mathrm{NH}) .{ }^{13} \mathrm{C}$ NMR $(\delta, \mathrm{ppm})$ : $14.40,22.37,28,82,28.88,44.17,116.77$, 
$122.35,124.78,131.12,133.68,159.20$, 160.87, 163.90. IR (KBr, cm-1): $3342 \mathrm{NH}$, $3058 \mathrm{CH}$ arom, $2963 \mathrm{CH}$ aliph., $1732 \mathrm{C}=\mathrm{O}$, $1613 \mathrm{C}=\mathrm{N}, 1476 \mathrm{C}-\mathrm{N}, 1364 \mathrm{C}=\mathrm{S}$. UV-Vis (nm) $\max 194,248$. Anal. calc. for $\mathrm{C}_{13} \mathrm{H}_{18} \mathrm{FN}_{3} \mathrm{OS}$ (\%): C 55.10; H 6.40; N 14.83. Found: C 55.25; H 6.52; N 14.97.

1-(2-Fluorobenzoyl)-4-(heptyl)thiosemicarbazide $2(75 \%) \mathrm{mp} 118-120^{\circ} \mathrm{C}$

${ }^{1} \mathrm{H}$ NMR $(\delta, \mathrm{ppm}): 0.85 ; 0.86 ; 0.87$ (t, $3 \mathrm{H}$, $\left.\mathrm{CH}_{3}, J=7.2 \mathrm{~Hz}\right), 1.23-1.29\left(\mathrm{~m}, 8 \mathrm{H}, 4 \mathrm{CH}_{2}\right)$, 1.48-1.53 (m, 2H, $\left.\mathrm{CH}_{2}\right), 3.43-3.44(\mathrm{~m}, 2 \mathrm{H}$, $\left.\mathrm{CH}_{2}\right), 7.30-7.33$ (m, 2H, $\mathrm{CH}$ arom), 7.57-7.61 (m, H, $\mathrm{CH}$ arom), 7.79; 7.80; $7.82(\mathrm{dt}, \mathrm{H}, \mathrm{CH}$ arom, $\left.J_{1}=1.8 \mathrm{~Hz}, J_{2}=6.0 \mathrm{~Hz}\right), 7.91 ; 9.35 ; 10.13$ $(3 \mathrm{~s}, 3 \mathrm{H}, 3 \mathrm{NH}),{ }^{13} \mathrm{C}$ NMR $(\delta, \mathrm{ppm}): 14.38$, $22.53,26.36,28.94,29,10,31.51,44.22$, $116.76,122.27,124.77,131.12,133.68$, 159.20, 160.86, 163.85. IR (KBr, cm-1): 3321 $\mathrm{NH}, 3162 \mathrm{CH}$ arom, $2968 \mathrm{CH}$ aliph., 1664 $\mathrm{C}=\mathrm{O}, 1614 \mathrm{C}=\mathrm{N}, 1474 \mathrm{C}-\mathrm{N}, 1370 \mathrm{C}=\mathrm{S}$. UVVis $(\mathrm{nm}) \max 195,248$. Anal. calc. for $\mathrm{C}_{15} \mathrm{H}_{22} \mathrm{FN}_{3} \mathrm{OS}(\%)$ : C 57.85; H 7.12; N 13.49. Found: C 57.85; H 7.30; N 13.62.

4-(Cyclopentyl)-1-(2-fluorobenzoyl)thiosemicarbazide 3 (92\%) mp $113-116^{\circ} \mathrm{C}$

${ }^{1} \mathrm{H}$ NMR $(\delta, \mathrm{ppm}): 1.45-1.54(\mathrm{~m}, 4 \mathrm{H}$, $\left.2 \mathrm{CH}_{2}\right), 1.61-1.66\left(\mathrm{~m}, 2 \mathrm{H}, \mathrm{CH}_{2}\right), 1.87-1.91(\mathrm{~m}$, $\left.2 \mathrm{H}, \mathrm{CH}_{2}\right), 4.56(\mathrm{~s}, 1 \mathrm{H}, \mathrm{CH}), 7.26-7.35(\mathrm{~m}, 2 \mathrm{H}$, $\mathrm{CH}$ arom $), 7.50-7.61(\mathrm{~m}, 2 \mathrm{H}, \mathrm{CH}$ arom $), 7.76$; $7.77 ; 7.79\left(\mathrm{dt}, 1 \mathrm{H}, \mathrm{CH}\right.$ arom, , $J_{1}=1.2 \mathrm{~Hz}$, $\left.J_{2}=6.0 \mathrm{~Hz}\right), 9.38 ; 9.53 ; 10.12(3 \mathrm{~s}, 3 \mathrm{H}, 3 \mathrm{NH})$. ${ }^{13} \mathrm{C} \mathrm{NMR}(\delta, \mathrm{ppm}): 23.90,32.24,55.99$, $116.62,122.32,123.63,130.41,133.62$, 158.71, 160.36, 163.77. IR (KBr, cm-1): 3356 $\mathrm{NH}, 3008 \mathrm{CH}$ arom, $2960 \mathrm{CH}$ aliph., 1667 $\mathrm{C}=\mathrm{O}, 1612 \mathrm{C}=\mathrm{N}, 1477 \mathrm{C}-\mathrm{N}, 1339 \mathrm{C}=\mathrm{S}$. UV-
Vis (nm) $\max 193,218,248$. Anal. calc. for $\mathrm{C}_{13} \mathrm{H}_{16} \mathrm{FN}_{3} \mathrm{OS}(\%)$ : C 55.50; H 5.73; N 14.94 . Found: C 55.55; H 5.80; N 14.98.

The procedure of synthesis of the 5-(2-fluorophenyl)-4-substituted-2,4dihydro-3H-1,2,4-triazole-3-thione (4-6)

The thiosemicarbazide derivatives were dissolved in $5 \mathrm{ml}$ of $2 \% \mathrm{NaOH}$. The mixtures were heated under reflux for 2 hours. Later the solutions were cooled down and acidified by $3 \mathrm{~N} \mathrm{HCl}$. The precipitates were filtered off, dried and crystallized from $96 \%$ ethanol.

5-(2-Fluorophenyl)-4-pentyl-2,4-dihydro$3 H-1,2,4-t r i a z o l e-3-t h i o n e ~ 4(50 \%) \mathrm{mp} 105-$ $108^{\circ} \mathrm{C}$

${ }^{1} \mathrm{H}$ NMR $(\delta, \mathrm{ppm}): 0.71 ; 0.72 ; 0.73(\mathrm{t}, 3 \mathrm{H}$, $\left.\mathrm{CH}_{3}, J=7.2 \mathrm{~Hz}\right), 1.01-1.05\left(\mathrm{~m}, 4 \mathrm{H}, 2 \mathrm{CH}_{2}\right), 1$. 07-1.11 (m, 2H, $\left.\mathrm{CH}_{2}\right), 1.46-1.51\left(\mathrm{~m}, 2 \mathrm{H}, \mathrm{CH}_{2}\right)$, 3.84-3.86 (m, $\left.2 \mathrm{H}, \mathrm{CH}_{2}\right), 7.42-7.44(\mathrm{~m}, 1 \mathrm{H}, \mathrm{CH}$ arom), 7.47-7.51 (m, 1H, $\mathrm{CH}$ arom), 7.67-7.73 (m, 2H, CH arom), $14.10(\mathrm{~s}, 1 \mathrm{H}, \mathrm{NH}) \cdot{ }^{13} \mathrm{C}$ NMR ( $\delta$, ppm): 13.99, 21.73, 27.29, 28.11, 44.01, 114.48, 116.72, 125.77, 132.49, 134.23, 146.97, 159.29, 167.52. IR ( $\left.\mathrm{KBr}, \mathrm{cm}^{-1}\right): 3058$ $\mathrm{CH}$ arom, $2963 \mathrm{CH}$ aliph., $1626 \mathrm{C}=\mathrm{N}, 1478$ C-N, $1363 \mathrm{C}=\mathrm{S}$. UV-Vis (nm) max 192, 259. Anal. calc. for $\mathrm{C}_{13} \mathrm{H}_{16} \mathrm{FN}_{3} \mathrm{~S}$ (\%): C 58.84; H 6.08; N 15.84. Found: C 58.90; H 6.30; $\mathrm{N} 15.94$.

5-(2-Fluorophenyl)-4-heptyl-2,4-dihydro3 H-1,2,4-triazole-3-thione 5 (64\%) mp 80$82^{\circ} \mathrm{C}$

${ }^{1} \mathrm{H}$ NMR $(\delta, \mathrm{ppm}): 0.79 ; 0.80 ; 0.82(\mathrm{t}, 3 \mathrm{H}$, $\left.\mathrm{CH}_{3}, J=7.2 \mathrm{~Hz}\right), 1.08-1.11\left(\mathrm{~m}, 6 \mathrm{H}, 3 \mathrm{CH}_{2}\right)$, 1.15-1.18 (m, $\left.2 \mathrm{H}, \mathrm{CH}_{2}\right), 1.52-1.56(\mathrm{~m}, 2 \mathrm{H}$, $\left.\mathrm{CH}_{2}\right), 3.89-3.92\left(\mathrm{~m}, 2 \mathrm{H}, \mathrm{CH}_{2}\right), 7.47 ; 7.48,7.49$ 
$\left(\mathrm{dt}, 1 \mathrm{H}, \mathrm{CH}\right.$ arom, $\left.J_{1}=1.2 \mathrm{~Hz}, J_{2}=6.6 \mathrm{~Hz}\right), 7.53-$ $7.56(\mathrm{~m}, 1 \mathrm{H}, \mathrm{CH}$ arom), 7.72-7.79 (m, 1H, CH arom), 14.14 (s, $1 \mathrm{H}, \mathrm{NH}) .{ }^{13} \mathrm{C}$ NMR $(\delta, \mathrm{ppm})$ : 14.33, 22.34, 25.67, 27.55, 28.93, 31.28, 43.99, $114.58,116.72,125.73,132.48,134.20$, 146.87, 160.93, 167.51. IR (KBr, cm-1): 3089 $\mathrm{CH}$ arom, $2948 \mathrm{CH}$ aliph., $1624 \mathrm{C}=\mathrm{N}, 1462$ $\mathrm{C}-\mathrm{N}, 1376 \mathrm{C}=\mathrm{S}$. UV-Vis (nm) $\max 193,259$. Anal. calc. for $\mathrm{C}_{15} \mathrm{H}_{20} \mathrm{FN}_{3} \mathrm{~S}$ (\%): C 61.40; $\mathrm{H}$ 6.87; N 14.32. Found: C 61.62; H 6.90; N 14.65 .

4-Cyclopentyl-5-(2-fluorophenyl)-2,4dihydro-3H-1,2,4-triazole-3-thione 6 (88\%) mp $180-182^{\circ} \mathrm{C}$

${ }^{1} \mathrm{H}$ NMR $(\delta, \mathrm{ppm}): 1.42-1.49\left(\mathrm{~m}, 2 \mathrm{H}, \mathrm{CH}_{2}\right)$, 1.59-1.65 (m, 2H, $\left.\mathrm{CH}_{2}\right), 1.81-1.86(\mathrm{~m}, 2 \mathrm{H}$, $\left.\mathrm{CH}_{2}\right), 2.28-2.34\left(\mathrm{~m}, 2 \mathrm{H}, \mathrm{CH}_{2}\right), 4.52-4.58(\mathrm{~m}$, $1 \mathrm{H}, \mathrm{CH}), 7.30-7.33$ (m, H, CH arom), 7.41; $7.42 ; 7.43\left(\mathrm{dt}, 1 \mathrm{H}, \mathrm{CH}\right.$ arom, $J_{1}=6.0 \mathrm{~Hz}, J_{2}=$ $6.6 \mathrm{~Hz}), 7.46-7.48(\mathrm{~m}, 1 \mathrm{H}, \mathrm{CH}$ arom), 7.63$7.73(\mathrm{~m}, 1 \mathrm{H}, \mathrm{CH}$ arom), 14.05 (s, 1H, NH).
${ }^{13} \mathrm{C}$ NMR $(\delta, \mathrm{ppm}): 25.00,28.84,57.69$, $116.57,124.91,125.66,133.06,134.25$, 147.08, 159.60, 166.60. IR (KBr, cm $\left.{ }^{-1}\right): 2970$ $\mathrm{CH}$ aliph., $1614 \mathrm{C}=\mathrm{N}, 1446 \mathrm{C}-\mathrm{N}, 1369 \mathrm{C}=\mathrm{S}$. UV-Vis (nm) max 193, 262. Anal. calc. for $\mathrm{C}_{13} \mathrm{H}_{14} \mathrm{FN}_{3} \mathrm{~S}$ (\%): C 59.29; H 5.36; N 15.96. Found: C 59.53; H 5.60; N 16.15 .

\section{Results and Discussion}

\section{Chemistry}

We have synthesized three new thiosemicarbazide derivatives and its cyclic analogues derivative from 2-fluorobenzoic acid hydrazide. The synthetic pathway is presented in Scheme 1.

The linear compounds (1-3) were obtained with simple and efficient method (yield in the range 75-92 \%). Alkaline cyclization of thiosemicarbazide using solution of sodium hydroxide led to the corresponding 5-(2-fluorophenyl)4-substituted-2,4-dihydro-3H-1,2,4-triazole-
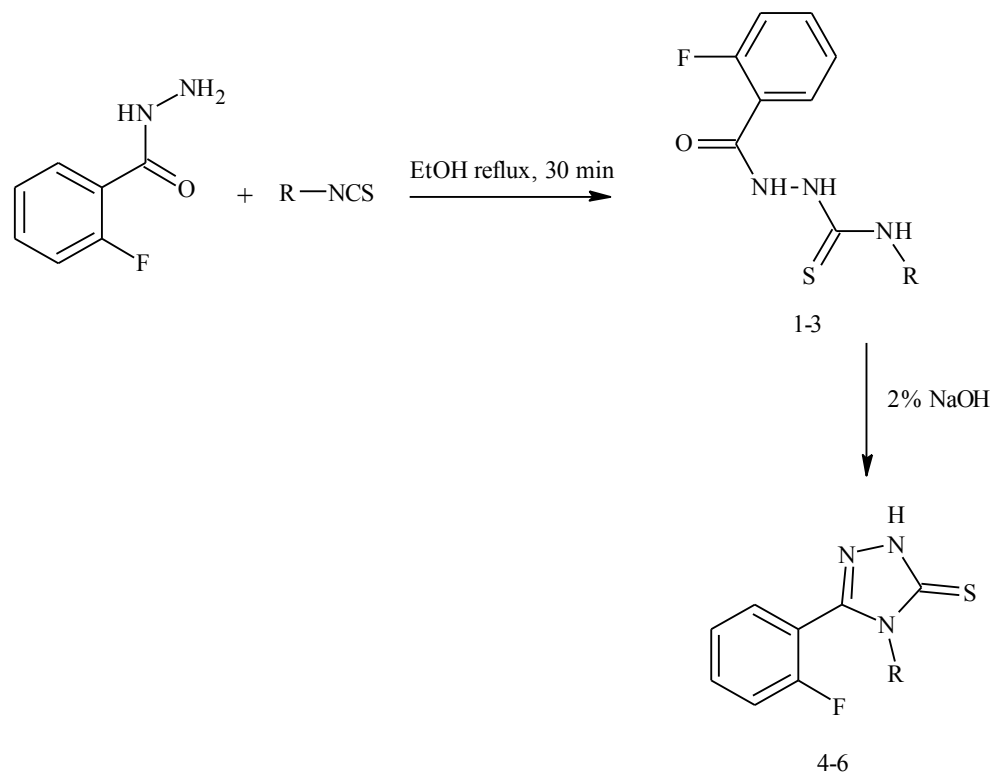

Scheme 1. Synthetic route for the compounds 1-6.

$\mathrm{R}=$ pentyl $(\mathbf{1}, \mathbf{4})$; heptyl $(2,5)$; cyclopentyl $(\mathbf{3}, \mathbf{6})$ 
3-thione (4-6) with good yield 50-88\%. The structures of all compounds were confirmed by elemental analysis and spectral methods: ${ }^{1} \mathrm{H}$ NMR, ${ }^{13} \mathrm{C}$ NMR, IR and UV-Vis spectroscopy. The spectra of thiosemicarbazides showed the signals of aromatic protons in the range 7.27-7.82 ppm, aliphatic protons at 0.85$4.56 \mathrm{ppm}$ and 3 singlets in the range 7.77$10.12 \mathrm{ppm}$ corresponding to 3 protons NHNHC(S)NH moiety. In the triazole derivatives the characteristic proton signals of the $\mathrm{NH}$ group were observed in the range 14.06$14.10 \mathrm{ppm}$. The ${ }^{13} \mathrm{C}$ NMR spectra of compounds 1-3 showed signals at 160.36$160,87 \mathrm{ppm}$ and $163.77-163.90 \mathrm{ppm}$ for $\mathrm{C}=\mathrm{S}$ and $\mathrm{C}=\mathrm{O}$ carbons, respectively. In the case of compounds 4-6 two signals corresponding to $\mathrm{NCN}$ and $\mathrm{C}=\mathrm{S}$ carbons were observed. In the IR spectra the characteristic absorption bands corresponding to $\mathrm{CH}$ aliphatic, $\mathrm{CH}$ aromatic, $\mathrm{C}=\mathrm{N}, \mathrm{C}-\mathrm{N}$ and $\mathrm{C}=\mathrm{S}$ groups were noticed. Compound 1, 2, 4-6 showed two maximum absorption in the UV-Vis in the range 192$195 \mathrm{~nm}$ and 248-262 $\mathrm{nm}$ whereas compound 3 demonstrated 3 maximum absorption.

\section{Docking Studies}

Molecular docking studies of anticonvulsant activity were estimated on GABA-A receptors (PDB code: 6HUP) [15] and pentameric ion channels from Erwinia chrysanthemi (ELIC) (pentameric ligand gated ion-channel from Erwinia chrysanthemums) as homolog model of GABA-A receptors (PDB code: 2YOE) [16]. Spatial structure of the designed compounds was performed using HyperChem 7.5 software. The structures of 2 YOE molecules were optimized by the method of molecular mechanics $\mathrm{MM}+$ with the achievement of
RMS gradient less than $0.1 \mathrm{kcal} /(\mathrm{mol} \AA)$. The final minimization of the energies of the investigated intermediates was carried out by the semi-empirical quantum chemical method PM3 until the RMS gradient was less than 0.01 $\mathrm{kcal} /(\mathrm{mol} \AA)$. The validation of selected docking parameters was performed by redocking the original ligands from three-dimensional enzyme structures (diazepam (Valium ${ }^{\circledR}$ ) with $6 \mathrm{HUP}$ and flurazepam with 2YOE). Additionally, binding energies were obtained for native ligands, which further allowed the assessment of the severity of anticonvulsant activity of the obtained compounds in comparison with the reference drugs. Docking was performed using the software package AutoDock Vina ${ }^{\circledR}$. Discovery Studio Visualizer software package was used to visualize and interpret the obtained data.

Table 1. Molecular docking binding energies on GABA-A receptor (code: 6HUP) and ELIC (code: 2YOE)

\begin{tabular}{l|c|c}
\hline \multirow{2}{*}{ Compound } & \multicolumn{2}{|c}{ Est. Binding Energy (kcal/mol) } \\
\cline { 2 - 3 } & GABA-A receptor & ELIC \\
\hline $\mathbf{1}$ & $-7,0$ & $-6,9$ \\
\hline $\mathbf{2}$ & $-7,2$ & $-6,8$ \\
\hline $\mathbf{3}$ & $-7,3$ & $-7,3$ \\
\hline $\mathbf{4}$ & $-7,0$ & $-6,3$ \\
\hline $\mathbf{5}$ & $-7,8$ & $-6,2$ \\
\hline $\mathbf{6}$ & $-8,5$ & $-7,0$ \\
\hline Diazepam & $-10,1$ & - \\
\hline Flurazepam & - & $-7,5$ \\
\hline
\end{tabular}

According to the docking studies results, the most promising are compounds $\mathbf{3}$ and $\mathbf{6}$ with cyclopentyl substituents in the molecule. The triazole analogs 4-6 showed higher binding energy in in silico modulation in comparison with the initial linear compounds 1-3. 

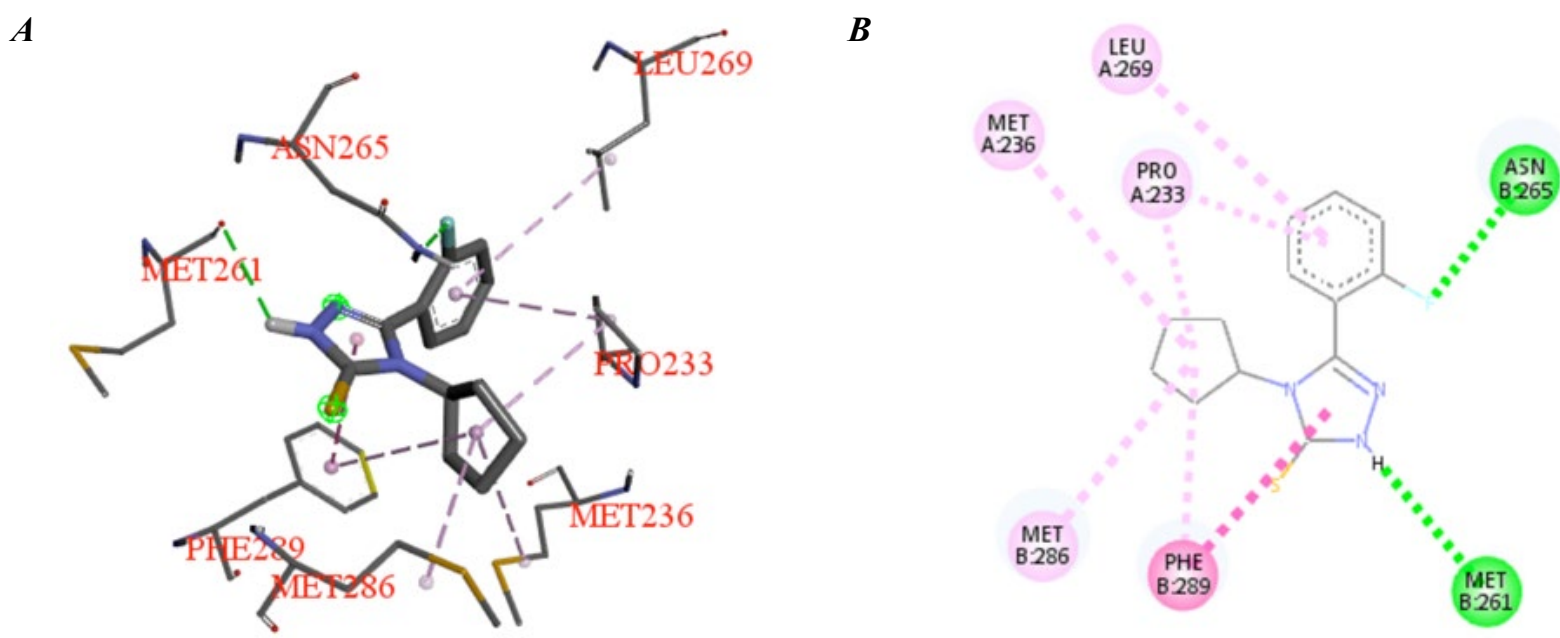

Fig. 1. Docked conformation of compound 6 with GABA-A receptor (PDB code: 6HUP)

The significant predicted anticonvulsant potential was observed for compound $\mathbf{6}$, which forms hydrogen bonds with a nitrogen atom of the triazole ring and methionine 261 with a length of $2.87 \AA$ and between a fluorine atom and asparagine 265 with a length of $2.65 \AA$ and Pi interaction with 5 more amino acids, namely methionine 286 , methionine 236 , proline 233 , leucine 269 and phenylalanine 289. These amino acids belong to the $\beta 3$ and $\alpha 1$ subunits of the GABA-A receptor. Noteworthy, the starting ligand of diazepam in this alloste-

A

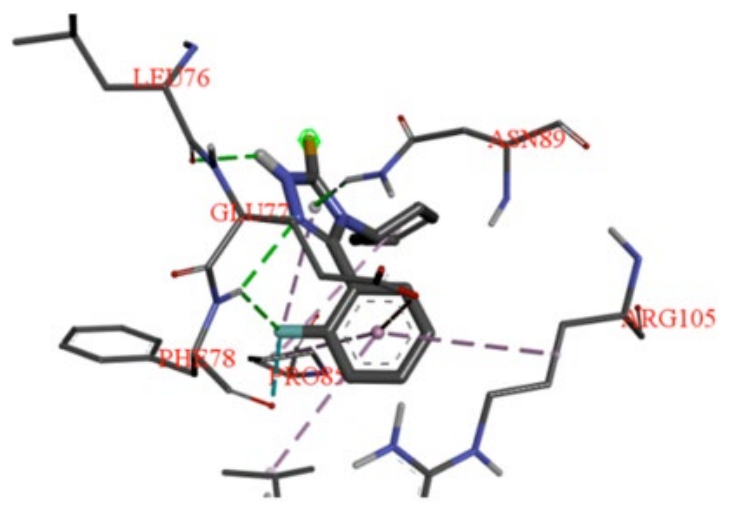

ric center forms hydrophobic interactions with the same amino acids.

The simulation of the interaction with ELIC led to high anticonvulsant potential of compound 6. It should be noted that the ELIC structure is quite limited due to derived from a prokaryotic cell as an analogue of GAMA-A receptors [16].

In conclusion, the binding energy of the obtained compounds, in particular the most active $\mathbf{6}$, is lower compared to the reference ligands from the original $\mathrm{X}$-ray images. It re-

$\boldsymbol{B}$

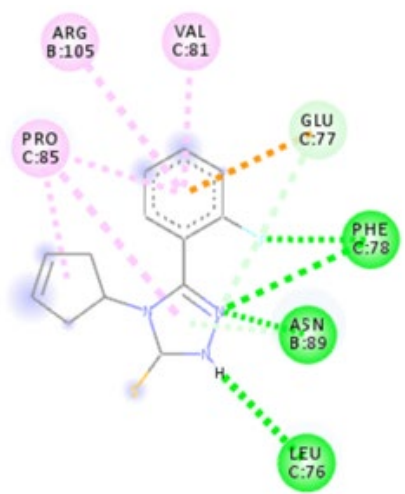

Fig. 2. Docked conformation of compound 6 with ELIC (PDB code: 2YOE) 
veals a deeper optimization of the spatial structure of the target molecules to enhance their anticonvulsant activity.

The interesting feature of GABA-A receptors is the interaction of agonists (benzodiazepines) and antagonists (flumazenil) with the same allosteric center, which is quite similar in their structure. The potential antagonistic effect of the synthesized compounds was estimated by docking studies on the model of GABA-A receptors (PBD code: 6D6T) and compared to the energy interaction of reference ligand flumazenil and several amino acids.

Table 2. Molecular docking binding energies on GABA-A receptor (code: 6D6T)

\begin{tabular}{l|c}
\hline \multicolumn{1}{c|}{ Compound } & Est. Binding Energy $(\mathrm{kcal} / \mathrm{mol})$ \\
\hline $\mathbf{1}$ & -8.5 \\
\hline $\mathbf{2}$ & -8.6 \\
\hline $\mathbf{3}$ & -9.0 \\
\hline $\mathbf{4}$ & -8.8 \\
\hline $\mathbf{5}$ & -8.2 \\
\hline $\mathbf{6}$ & -8.5 \\
\hline Flumazenil & -9.4 \\
\hline Diazepam & -10.1 \\
\hline
\end{tabular}

The main requirement for the antagonistic effect of flumazenil is an interaction with HIS102 and a lipophilic pocket formed by aromatic amino acids TYR160, TYR210, PHE100, PHE77. The position of the molecule in the allosteric center is stabilized by the hydrogen bonds with TRH142 [17].

According to docking studies, compound 3 was the most active with the highest binding energy. However, the main requirement for active molecules is the interaction with HIS102 for both agonistic and antagonistic effects, because the replacement of mentioned amino acid decreases the sensitivity of the receptor to both benzodiazepine and flumazenil [18].

As can be seen in the figure 4, the high interaction energy is achieved due to the formation of two hydrogen bonds with SER205 and SER206. However, there is no interaction with HIS102, which is a key element in the manifestation of both agonistic and antagonistic effects. There is also a weak interaction with one aromatic amino acid TYR206 from the above-mentioned lipophilic pocket. The similar process we observed for compound $\mathbf{1}$, although the interaction energy is quite lower.

The comparison of the interaction of compound 6 and diazepam with the allosteric center of the GABA-A receptor, as we observed on HIS102 is a key in the manifestation of pharmacological effects. Interestingly, compound 6 is predicted to form two hydrogen bonds with TYR210 and SER205, 3.58 A and $2.01 \mathrm{~A}$, respectively, which can significantly stabilize the position of the molecule. However, it should be noted that the binding energy in this case is lower as compared to reference drugs, which indicates the need of further docking studies and evaluation of the structure-activity relationship.

\section{Conclusion}

We described efficient and facile synthesis of some new compounds with potential anticonvulsant activity. The structures of all compounds were uniquely confirmed using IR, UV-Vis, ${ }^{1} \mathrm{H}$ and ${ }^{13} \mathrm{C}$ NMR spectra. According to the docking studies results, two compounds with cyclopentyl substituents are the most promising. The triazole analog $\mathbf{6}$ showed a higher binding energy in silico modulation in comparison with the initial linear compound 3 . 


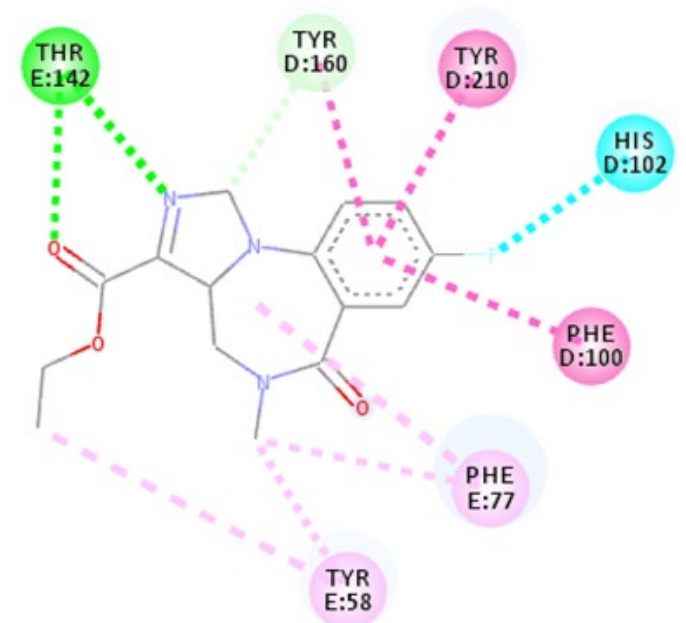

Interactions

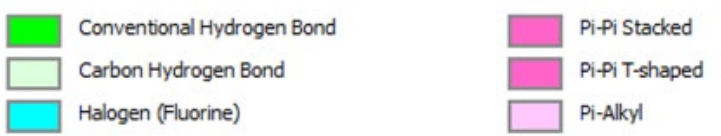

Fig. 3. Docked conformation of Flumazenil with GABA-

A receptor

$\boldsymbol{A}$

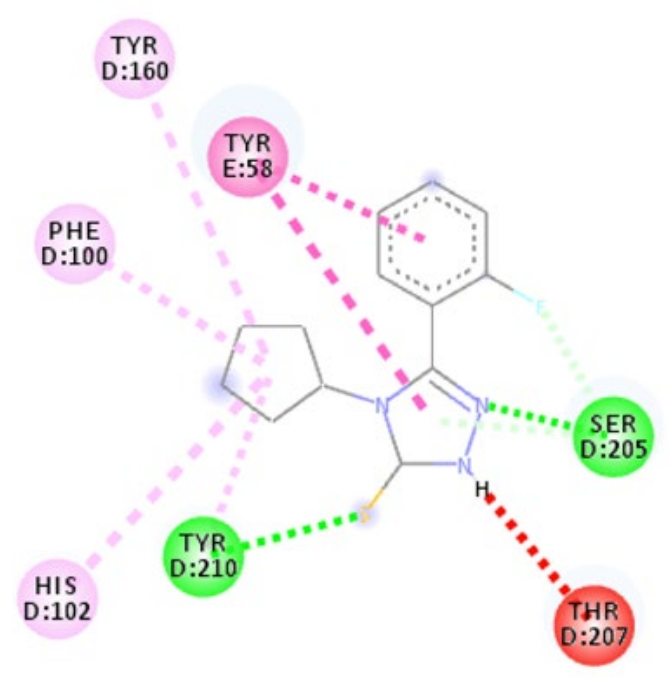

Interactions

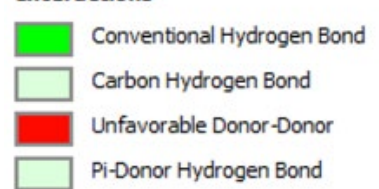

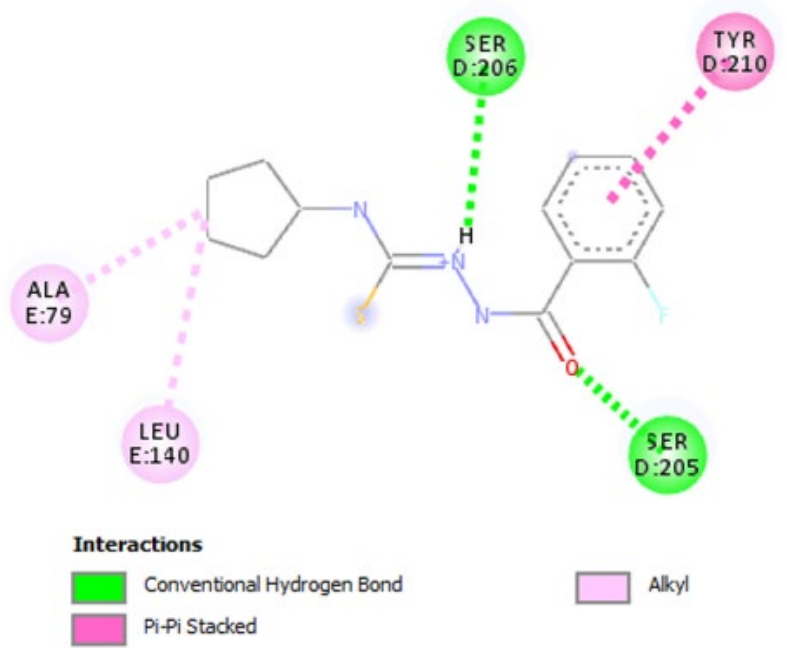

Fig. 4. Interaction of compound 3 with amino acids of the allosteric center.

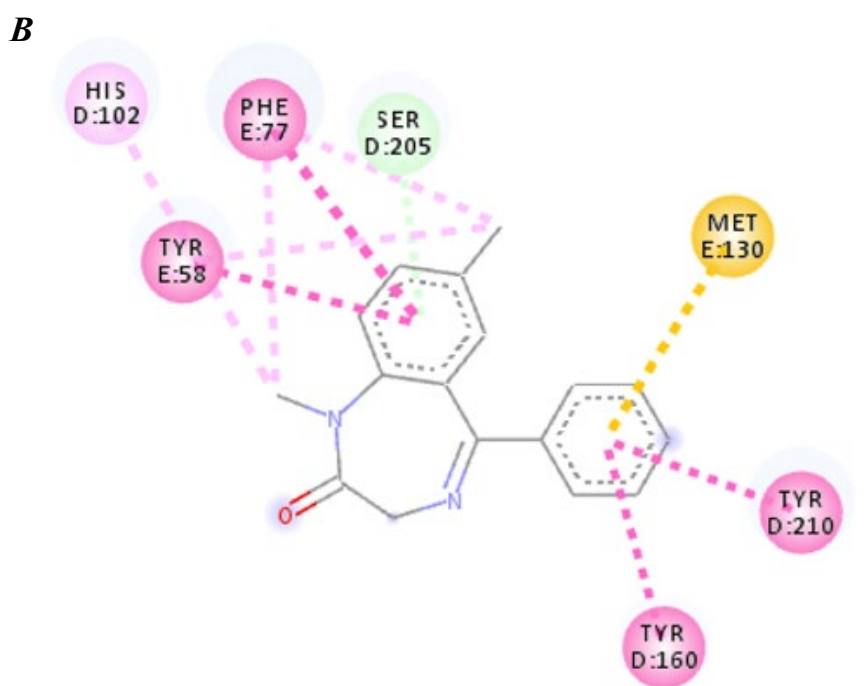

Interactions

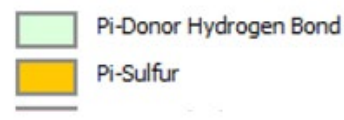

Pi-Pi T-shaped Pi-Alkyl

Fig. 5. Interaction of compound 6 and diazepam within the allosteric center of the GABA-A receptor 


\section{REFERENCES}

1. Savage N. Epidemiology: The complexities of epilepsy. Nature. 2014; 511(7508):S2-S3.

2. Heja L. Astrocytic target mechanisms in epilepsy. Curr Med Chem. 2014; 21(6):755-763.

3. Kaminski RM, Rogawski MA, Klitgaard H. The potential of antiseizure drugs and agents that act on novel molecular targets as antiepileptogenic treatments. Neurotherapeutics. 2014; 11(2):385400.

4. Meldrum BS, Rogawski MA. Molecular targets for antiepileptic drug development. Neurotherapeutics. 2007; 4(1):18-61.

5. Mantegazza M, Curia G, Biagini G, Ragsdale DS, Avioli $M$. Voltage-gated sodium channels as therapeutic targets in epilepsy and other neurological disorders. Lancet Neurol. 2010; 9(4):413-424.

6. Lipkind GM, Fozzard HA. Molecular model of anticonvulsant drug binding to the voltage-gated sodium channel inner pore. Mol Pharmacol. 2010; 78(4):631-638.

7. Wingrove $P B$, Wafford KA, Bain C, Whiting PJ. The modulatory action of loreclezole at the $\gamma$-aminobutyric acid type A receptor is determined by a single amino acid in the $\beta 2$ subunit. Proc Natl Acad Sci USA. 1994; 91(10):4569-4573.

8. Shalini M, Yogeeswari P, Sriram D, Stables JP. Cyclization of the semicarbazone template of aryl semicarbazones: Synthesis and anticonvulsant activity of 4,5-diphenyl-2 $\mathrm{H}$-1,2,4-triazol-3(4H)-one. Biomed Pharmacother. 2009; 63(3):187-193.

9. Siddiqui $N$, Ahsan $W$. Triazole incorporated thiazoles as a new class of anticonvulsants: Design, synthesis and in vivo screening. Eur J Med Chem. 2010; 45(4):1536-1543.

10. Almasirad A, Tabatabai SA, Faizi M, Kebriaeezadeh A, Mehrabi N, Dalvandi A, Shafiee A. Synthesis and anticonvulsant activity of new 2 -substituted5-[2-(2-fluorophenoxy)phenyl]-1,3,4-oxadiazoles and 1,2,4-triazoles. Bioorg Med Chem Lett. 2004; 14(24):6057-6059.

11. Akbarzadeh T, Tabatabai SA, Khoshnoud MJ, Shafaghi $B$, Shafiee A. Design and synthesis of 4H-3-(2phenoxy)phenyl-1,2,4-triazole derivatives as ben- zodiazepine receptor agonists. Bioorg Med Chem. 2003; 11(5):769-773.

12. Plech T, Łuszczki JJ, Wujec M, Flieger J, Pizoń M. Synthesis, characterization and preliminary anticonvulsant evaluation of some 4-alkyl-1,2,4-triazoles. Eur J Med Chem. 2013; 60:208-215.

13. Plech T, Kaproń B, Luszczki JJ, Wujec M, Paneth A, Siwek A, Kołaczkowski M, Żotnierek M, Nowak G. Studies on the anticonvulsant activity and influence on GABA-ergic Neurotransmission of 1,2,4-triazole-3-thione-based compounds. Molecules. 2014; 19(8):11279-11299.

14. Smart E. Fluorine substituent effects. J Fluorine Chem. 2001; 109(1):3-11.

15. Masiulis S, Desai R, Uchański T, Martin IS, Laverty $D$, Karia $D$, Malinauskas T, Zivanov J, Pardon E, Kotecha A, Steyaert J. GABA A receptor signalling mechanisms revealed by structural pharmacology. Nature. 2019; 565:454-459.

16. Spurny R, Ramerstorfer $J$, Price K, Brams $M$, Ernst $M$, Nury $H$, Verheij $M$, Legrand P, Bertrand $D$, Bertrand $S$, Dougherty $D A$. Pentameric ligandgated ion channel ELIC is activated by GABA and modulated by benzodiazepines. Proc Natl Acad Sci USA. 2012; 109(44):E3028-E3034.

17. Zhu S, Noviello CM, Teng J, Walsh RM, Kim JJ, Hibbs RE. Structure of a human synaptic GABA A receptor. Nature. 2018; 559(7712):67-72.

18. Dunn SM, Davies M, Muntoni AL, Lambert JJ. Mutagenesis of the rat $\alpha 1$ subunit of the $\gamma$-aminobutyric acidA receptor reveals the importance of residue 101 in determining the allosteric effects of benzodiazepine site ligands. Molecular pharmacology. 1999; 56(4):768-774.

\section{4-Алкіл-1-(2-фторбензоїл)тіосемікарбазиди та продукти їх дегідроциклізації як сполуки 3 потенційною протисудомною активністю}

\section{I. Чижевська, Е. Кусьмєш, М. Вуєц}

Мета. Здійснити синтез нових тіосемікарбазидів та їх циклічних аналогів, отриманих з гідразиду 2-фторобензойної кислоти для вивчення їх протисудомної активності. Методи. Органічний синтез, спектроскопія ЯМР, молекулярний докінг. Результати. Взаємодією гідразиду 2-фторобензойної кислоти 3 
відповідними ізотіоціанатами в середовищі етанолу синтезовано ряд нових тіосемікарбазидів. Подальша лужна дегідроциклізація тіосемікарбазидів призвела до отримання похідних 1,2,4-тріазолу. Для прогнозування антиконвульсивної активності для синтезованих сполук були проведені докінгові дослідження на GABA-A рецепторах та пентамеричних йонних каналах Erwinia chrysanthemi (ELIC). Висновки. Синтезовані тіосемікарбазиди та їх циклічні аналоги є перспективною молекулярною платформою для розробки нових високоактивних сполук як потенційних протисудомних лікарських засобів.

Кл юч о в і сл ов а: тіосемікарбазиди, 1,2,4-тріазоли, протисудомна активність

\section{4-Алкил-1-(2-фторбензоил)тиосемикарбазиды и продукты их дегидроциклизации как соединения с потенциальной противосудорожной активностью}

И. Чижевская, Э. Кусьмеш, М. Вуец

Цель. Осуществить синтез новых тиосемикарбазидов и их циклических аналогов, полученных из гидразида 2-фторбензойной кислоты для изучения их противосудорожной активности. Методы. Органический синтез, спектроскопия ЯМР, молекулярный докинг. Результаты. Взаимодействием гидразида 2-фторбензойной кислоты с соответствующими изотиоцианатами в среде этанола синтезировано ряд новых тиосемикарбазидов. Дальнейшая щелочная дегидроциклизация тиосемикарбазидов привела к получению производных 1,2,4-триазола. Для прогнозирования антиконвульсивной активности для синтезированных соединений были проведены докинговые исследования на GABA-A рецепторах и пентамеричних ионных каналах Erwinia chrysanthemi (ELIC). Выводы. Синтезированные тиосемикарбазиды и их циклические аналоги являются перспективной молекулярной платформой для разработки новых высокоактивных соединений как потенциальных противосудорожных лекарственных средств.

К л юч е в ы е с л о в а: тиосемикарбазиды, 1,2,4-триазолы, противосудорожная активность

Received 05.06.2020 